\title{
Ocorrência da ferrugem (Puccinia substriata var. penicillariae) do milheto na região Oeste do Estado do Paraná
}

\author{
Antonio Carlos Torres da Costa ${ }^{1}$, José Renato Stangarlin ${ }^{1}$, Gilmar Franzener ${ }^{1}$
}

\begin{abstract}
${ }^{1}$ Centro de Ciências Agrárias, Universidade Estadual do Oeste do Paraná (UNIOESTE), Campus de Marechal Cândido Rondon. Rua Pernambuco 1777, Centro. Caixa Postal 91, 85960-000, Marechal Cândido Rondon, PR, Brasil.

Autor para correspondência: José Renato Stangarlin ( jrstangarlin@ unioeste.br)

Data de chegada: 17/12/2007. Aceito para publicação em: 20/02/2008
\end{abstract}

O milheto pérola [Pennisetum glaucum (L) R. Brown] é utilizado no Brasil para produção de forragem e para a produção de grãos usado no fabrico de ração animal. Nos últimos anos, esta cultura se tornou de fundamental importância para a produção de palhada no sistema de plantio direto, havendo um aumento considerável da área plantada. Entretanto, um grande problema econômico para esta cultura tem sido a ferrugem, pois os danos causados por esta doença resultam em redução de rendimento de até $75 \%$ da produção de grãos, além de reduzir tanto a produção de biomassa como a qualidade da forragem. No Brasil, sintomas de ferrugem nas folhas de milheto foram inicialmente observados em 1997, na área experimental da Embrapa Cerrados, em lavouras comerciais no Distrito Federal e em municípios vizinhos de Minas Gerais e Goiás e, em 1999, na área experimental no campus da UFRuralRJ, Rio de Janeiro. Em experimento instalado em dezembro de 2006, na Estação Experimental Prof. Dr. Antônio Carlos dos Santos Pessoa, pertencente ao Núcleo de Estações Experimentais da Universidade Estadual do Oeste do Paraná (UNIOESTE), campus de Marechal Cândido Rondon, foram observados, a partir do mês de fevereiro de 2007, sintomas de ferrugem nas folhas de milheto, caracterizados pela presença de pústulas de cor alaranjada e de cor escura (Figura 1A e B). Folhas naturalmente infectadas foram analisadas no laboratório de Fitopatologia da UNIOESTE e depositadas em seu Herbário sob o número 312/08. Para a identificação do agente etiológico, esporos coletados das pústulas foram observados ao microscópio. Constatou-se a presença de urediniósporos ovóides a elipsóides, unicelulares e alaranjados, com dimensões médias de 35 x $28 \mu \mathrm{m}$ (Figura 1C), e teliósporos bicelulares com pedicelos
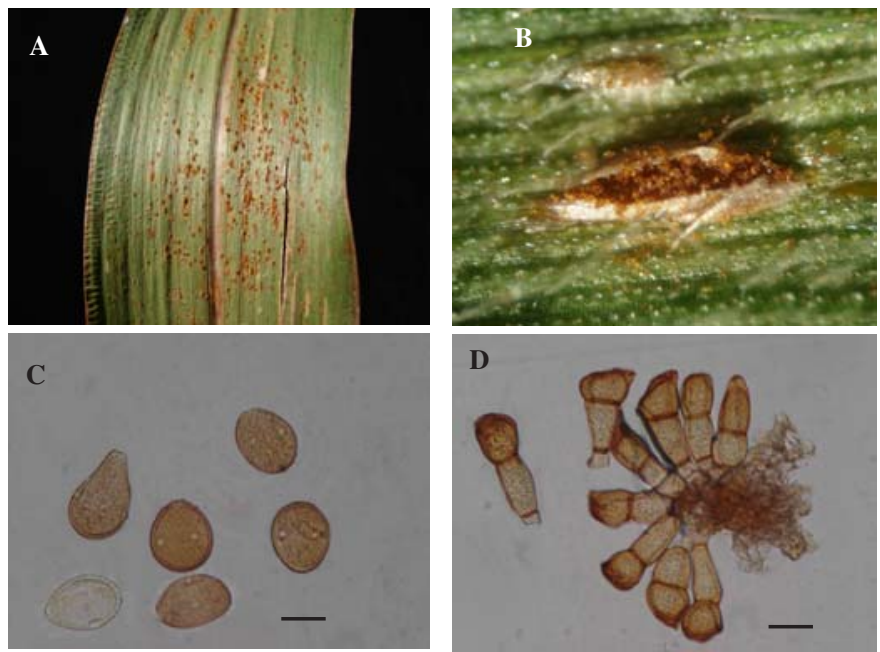

Figura 1. Sintomas da ferrugem causada por Puccinia substriata var. penicillariae em milheto (A), com detalhes da pústula (B), dos urediniósporos (C) e teliósporos (D). Barras representam $20 \mu \mathrm{m}$.

longos, apresentando comprimento superior a $20 \mu \mathrm{m}$ e coloração escura (Figura 1D). Estas dimensões estão de acordo com as relatadas para esta espécie (Carvalho et al. - Mycopathologia 161:331-336, 2006). O patógeno foi identificado como sendo Puccinia substriata var. penicillariae, agente causador da ferrugem do milheto. Este é o primeiro relato da ocorrência da ferrugem em milheto na região Oeste do Estado do Paraná. 